\title{
Strategy Mode Research on China shale gas development be introduced to social capital
}

\author{
Zhiwu HE \\ Cooperation and Development Department \\ ChongQing University of Science \& Techlology \\ ChongQing, China
}

\begin{abstract}
First, the Chinese government positions shale gas as an independent mineral, in one hand, it is meant to avoid the exploration and development of oil and other state-owned monopoly franchise constraints, on the other hand, private capital can be involved in such a huge potential for energy industry in the past, so that the shale gas industry to fully realize the market competition. China Land and Resources issued <<the notice on the strengthening of shale gas exploration and exploitation of resources and supervision of the work > which required that China shale gas exploration and exploitation implements the "open market" principle, according to the law society to encourage all types of investors into the shale gas exploration mining fields. China's conventional oil and natural gas exploration and exploitation faced by the high threshold, the Chinese officials encourage qualified private enterprises to invest in exploration and mining of shale gas; at the same time, encourage foreign companies who have shale gas exploration and mining technology to take the form of joint venture, cooperative to participate China shale gas exploration and exploitation. $<<$ Notice >> points that the Ministry of Land Resources is responsible for shale gas exploration and mining of the registration and management, primarily to sell shale gas exploration rights by way of competitive bidding.
\end{abstract}

Keywords- shale gas; exploration and exploitation; investment

\section{INTRODUCTION}

China shale gas development is still in gestation, infancy. While there are still some current problems in China's shale gas development system, the core technology, such as technical level is relatively backward, low degree of specialization, but shale gas development has been highly concerned by the community, social capital investment also in high spirits. China also has abundant reserves of shale gas, can be comparable with the United States. Petroleum and petrochemical industry in China Development Summit held in May this year, experts say, China's shale gas reserves are substantial and broad development prospects. Another data show that shale gas exploration in the Sichuan Basin in southwest will bring us good news. If you can actively learn from foreign experience, innovation, key technologies to carry out shale gas, and preferential policies to support and actively promote, slowly and surely, China is bound to be able to go out of their way to shale gas development.

Since the CPC Central Committee and State Council on the promotion of central China be issued, China unveiled a

\author{
Yan JIANG \\ Cooperation and Development Department \\ ChongQing University of Science \& Techlology \\ ChongQing, China
}

"Plan for the central region," a number of policy measures to promote the rise of central China. The release of "opinions" required, improve the level of energy and raw material base for development. Petrochemical and other industries to promote restructuring, extend the industrial chain, improve product value and competitiveness, strengthen raw materials, industrial, promote the construction of rational layout, and highlight the advantages of system integrity, safety and environmental protection materials, deep processing base. Meanwhile, in order to master the core technology breakthrough, fostering the development of biological medicine, new energy, new materials and other strategic emerging industries, vigorously implement the major industrial development of innovative projects and emerging industries of strategic innovations application in Van project. When China Petroleum and Chemical Industry Association Deputy Secretary-General Sun Weishan was interviewed by reporters said that central region should take this opportunity to fully play to the east and west of the regional advantages, expand the local petrochemical industries, focusing on the development of coaled methane utilization, high clean conversion of low-quality coal sulfur, phosphorus chemical industry, new materials industry, first-class, while accelerating to undertake international industrial transfer and eastern regions.

\section{THE STATUS OF CHINA SHALE GAS DEVELOPMENT}

Coal dominates China's energy demand, but burning coal releases large amounts of harmful substances. In the recent two years, most of the northern cities have haze frequently in four seasons, and spread to the south, air quality of whole east China is declining by years. With China's economic development, the growing demand for clean energy is increasing; also in 1992 China has become a major energyimporting country. Therefore, in the background of worsening energy supply and air quality, natural gas will become an important alternative to traditional energy sources coal. Shale gas development has been incorporated into our energy strategy plan, $<<$ The $12^{\text {th }}$ five-Year plan of National Economic and Social Development $>>$ clearly put forward to promote the development and utilization of coal-bed methane, shale gas and other unconventional oil and gas resources." In the year of 2011, the National Development and Reform Commission and other four ministries jointly launched the <<shale gas development plan (2011 - 2015)>>, the Ministry co-optimized 180 favorable block. At present, China has entered a substantive shale gas exploration stage, 
which is mainly in the Sichuan Basin and its adjacent areas, the Ordos Basin, Liaodong depression and other places. Chinese oil in southern Sichuan has drilled about 20 gas wells, with an average daily production more than $10000 \mathrm{~m} 3$ per well; Chinese Sinopec in eastern Guizhou, Anhui and eastern Sichuan drilled five appraisal wells, which includes two wells to obtain industrial air; CNOOC in Anhui and Zhejiang, Shanxi and other regions also carried out preliminary exploration work, apply a favorable shale gas exploration area; extended Petroleum in Yan'an of Shaanxi and found three shale gas wells. Individual shale gas project achieved commercial operation, but not for large-scale commercial exploitation. The famous Chinese expert on shale gas resources Professor Zhang Jinchuan believes that China's shale gas development can be divided into the exploration phase, drilling and production phases and commercial application stage. From the current domestic situation, there is no energy company can meet the conditions of the requirements of these three stages, the domestic oil companies in shale gas exploration are close to international standards, the core problem is that the drilling and production and commercial application stage. In China, the commercial development of shale gas still has a long way, but it can be gradually improved framework and environmental protection laws \&regulations for shale gas development.

Natural gas as a clean low-carbon fuel is the future direction of energy development. In recent years, the sudden emergence of US shale gas revolution, which has input a powerful impetus for the development of the world's large natural gas and set an example of our shale gas development. It is estimated that the United States Geological Survey, China shale gas technically recoverable reserves reached 36 trillion cubic meters, ranking first in the world; and according to the assessment of Land and Resources, China's shale gas reserves 25 trillion cubic meters, Which still is the world's No.1. At present, China's conventional natural gas reserves only 5 trillion cubic meters, comparing to conventional natural gas, shale gas reserves are five times that of conventional natural gas. This means that all of a sudden our natural gas reserves increased five-fold, reaching 30 trillion cubic meters. Yield is calculated by now about 100 billion cubic meters a year, you can continue to develop 300 years, and the great potential of shale gas development is evident. US yield surge of shale gas development sharply increase 20 times for nearly 10 years, which leapfrogged Russia became the world's largest natural gas producer, entered the "energy independence" of the door. This gives China with great incentives. The Chinese government will develop shale gas rose to national energy strategy, the shale gas has been treated as an independent mineral, the <<shale gas development plan (2011-2015)>> was released in February this year, but also to promote the second round in September, breaking the state-owned monopoly oil and gas resources policy in the past, and fully open to all types of investors at home and abroad, and actively promote the development of shale gas. Active support of the Government, various domestic and international capital are long for trying, are hoping to share the cake of China shale gas revolution.

China Petroleum has done the work of shale gas development pilot demonstration in Sichuan Changning, Wei Yun, Zhaotong and other places. Currently, Sichuan Changning - Weiyun block has been included in the national shale gas demonstration area. The China National Offshore Oil shale gas carried out preliminary exploration in Anhui and Zhejiang, the first of its onshore oil and natural gas (shale gas) exploration project -shale gas exploration projects begin seismic operations under west Yangtze block of Wuhu. The block covers an area of over 4800 square kilometers. Recently, the National Development and Reform Commission approved the establishment of "Extend the national Yanchang Petroleum of continental shale gas demonstration zone", an area of 4000 square kilometers, built capacity of 500 million cubic meters or more. In 2011, to extend the commitment of the Ordos Basin in southeastern oil shale and efficient development of demonstration projects, drilled our first port of continental shale gas wells and fracturing success, it has been successfully drilled 16 shale gas wells so far, in addition, oil and gas companies seize opportunities in shale gas development, the domestic coal and electricity giants have begun to get involved in shale gas industries. Henan CBM Corp., mainly engaged in coal-bed methane and other unconventional gas development, who firstly has won the bid of Chongqing and Guizhou, Hunan Xiushan shale gas exploration in July 2011, where covers an area of 2038 square kilometers. On $12^{\text {th }}$ September this year, the company has signed a strategic technology alliance framework agreement with the US Halliburton Energy Services Corp., they will deeply cooperate on shale gas and other unconventional gas exploitation. Cooperating with foreign oil and gas companies, drawing on foreign technology to accelerate shale gas development, is an often used strategic by domestic enterprises for the development of shale gas. And recently, the provincial government reached an agreement with China Huadian Group, will actively promote shale gas resources survey and evaluation in Hunan and choose two favorable exploration blocks of Western for implementation, to take a development and utilization of distributed energy demonstration area construction. Nuclear Group said it will cooperate with Hunan Bureau of Energy on shale gas development, actively involved in shale gas development in Hunan Province.

\section{OPPORTUNITIES FOR INVESTMENT IN CHINESE SHALE GAS INDUSTRIAL CHAIN}

China shale gas upstream investment opportunities, primarily for China shale gas upstream exploration, development and mining of gas phase. Shale gas exploration and development is the most important thing at this stage. According to the background of production demonstration and block tender conditions, in accordance with the number of single well costs and wellhead forecast 2015 domestic shale gas exploration and development with a total investment of about RMB 20 billion. By the development of 
pattern classification, enter into the development phase or basic capacity demonstration area 160-180 billion, in tender evaluation stage exploration blocks $20-40$ billion. By subsub-sector investment classification, where exploration RMB 150 million, OCTG RMB 1.68 billion, drill mud RMB1.68 billion, rig rental RMB 2.24 billion, wellsite preparation RMB 1 billion, RMB 720 million for cement, completion equipment and tools RMB 15 billion, RMB 6.8 billion for fracturing services, logging RMB 800 million and so on.

Global oil and gas field equipment and services market trend have changed in 2011, fracturing services market beyond offshore drilling, offshore oil and gas field equipment and construction become the market leader in the sub-services. Compared to other sub oilfield services market stock growth, we are more optimistic about the country to benefit from the decay of old oil and gas fields to increase production, the new low-permeability oil and gas wells in the space field to build larger, more flexible fracturing services market, and expected in 2012 global pressure split \$50 billion services market. Compared to the stock of oil and gas exploration and development of general equipment industry growth, we are more optimistic about the popularity and growth of special equipment. Applied high-tech special equipment such as fracturing in tight gas development in training, in the large-scale development of shale gas in advance in unconventional oil and gas exploration and development and expected that domestic cumulative market would be around $\$ 20$ billion before 2015 .

\section{BROKE SUBSTANTIVE MONOPOLY OF CENTRAL OIL PRICES IN MANY AREAS}

Carry out detailed studies of shale gas resource base, given the success of exploration companies get the full benefits from the system protection; according to the characteristics of shale gas development, refinement rules to attract foreign investment and encourage foreign investment; actively expand the capital market innovative financing investment patterns to attract private and foreign companies, development cooperation and the formation of multi-risk investments that match; pay close attention to the environmental impact of shale gas development, introduce specific\& practicable regulatory as soon as possible, coordinate at the same national level, and consider appropriate mechanism for local governments, nongovernmental organizations and local communities participate in environmental monitoring work, form good communication between stakeholders. In addition, for issue appeared in the second round of bidding for shale gas block, the central enterprises should be abolished now shale gas blocks of tenements, redesigned shale gas mineral rights mechanisms, block out high quality bid to the nation, forcing central enterprises to participate in bidding, rather than rely on the government to provide special policy monopoly of resources and increase the punishment for commitment of the winning companies who could not be reached.

\section{DIVERSIFIED BUSINESS COOPERATION}

Diversification of inter-firm cooperation embodied in the main mode of cooperation and collaboration. Look from the cooperative mode, from 2007 the first foreign oil signed a cooperation agreement, the Chinese company's external cooperation model is evolving, there are four modes such as production sharing contracts, joint venture, merger and acquisitions, contract services business. Among them, the most be used is the equity acquisition mode. From the comain view, with the development of shale gas in China, more and more enterprises get involved into shale gas development. As can be seen from Table 2, not only "three barrels of oil" currently working on the development of shale gas, there are many other companies, such as Huadian Group, Shenhua Group, Qingdao Jin Wang Group, Henan CBM company, Chongqing Energy Group. Furthermore, Land and Resources issued on the strengthening of shale gas exploration and exploitation of resources and supervision work in November 2012, which clearly encourage all types of investors to enter the shale gas fields. As many experts predict, shale gas development is likely to break the "three barrels of oil" monopoly favorable opportunity.

\section{CONCLUSIONS}

International cooperation is beneficial ways to accelerate the development of shale gas, but historical experience shows that the way of international cooperation does not help China to get core technology in shale gas development. From 2009 to the present, both intergovernmental cooperation and cooperation between enterprises have made great progress, but China has yet to grasp the horizontal well fracturing technology. In addition, China and the US Geological conditions are in great differences, American shale gas geological conditions are good and conducive to explore, while most of China's shale gas are in the mountains, with a deep gas reservoir, complex geological conditions and other characteristics, it is impossible to copy the US technology. While international cooperation of China shale gas has made great progress, but tackle problems in key technologies are still the most important.

\section{References}

[1] Zhou Xiaolai Business Opportunities of China shale gas industry [J] Shanghai Energy Conservation, 2013,09: 14-18 + 23 .

[2] Wang ChangJin. China's shale gas [J] Chinese new era, 2012,07: 4.

[3] The second round of bidding for shale gas prospecting and start $[\mathrm{J}]$ China Petroleum and Chemical Industry, 2012,10: 33.

[4] Qu Xiaowei Investment boom in shale gas plays [J] China Petrochemical, 2012,12: 10-12.

[5] Liu Guoliang. Summary of Research on Social Capital and Economic Growth [J] Industry Economic Review, 2004,02: 24-34.

[6] Huan Qingping. Community ritual and its role in the community social capital creation - A field study northwest bow village "turn lights' ceremony as an example [J] Northwest Ethnic Studies, 2003,04: $121-126+145$.

[7] Liu Yajing. Governance of Public Safety based on the domain of social capital [J] Petition and social conflicts Research, 2014,04: 98106. 